\title{
MięDZYNARODOWA KONFERENCJA
}

„EgodokUMENTY. TRAdyCJE hiSTORIOGRAFICZNE PERSPEKTYWY BADAWCZE”

http://dx.doi.org/10.12775/AKZ.2014.011

$\mathbb{W}$ latach 50. XX w. holenderski badacz memuarystyki, Jacob Presser ${ }^{1}$, ukuł pojęcie egodokumentu. Dotyczy ono źródeł - dzienników, pamiętników, itinerariów, autobiografii, listów - w których mamy do czynienia z "Ja" piszącego. Wedle zmarłego w 1970 r. badacza wszystkie te źródła mogą być rozpatrywane razem, gdyż mają właściwości autobiograficzne. We wszystkich autor świadomie bądź mimowolnie ujawnia własne dążenia i świat wartości - własne ego. Mogą one posłużyć za obraz jednostki, a nawet świadectwo mentalności większych grup. Neologizm oraz cała idea holenderskiego uczonego szybko znalazła uznanie wśród historyków, literaturoznawców i kulturoznawców. Obecnie rozwijana jest przez holenderskich (Rudolf Dekker, Arianne Baggerman z Center for the Study of Egodocuments and History), niemieckich (Claudia Ulbricht) czy francuskich (François-Joseph Ruggiu, Sandrine Mouysset) badaczy ${ }^{2}$.

Badania nad egodokumentami prowadzone są również w Europie Wschodniej. Przeglądem studiów oraz refleksją nad koncepcją egodokumentu na gruncie litewskim i polskim stała się międzynarodowa konferencja „Egodokumenty. Tradycje historiograficzne - perspektywy badawcze” zorganizowana przez Wydział Komunikacji Uniwersytetu Wileńskiego, Wydział

1 Jacques Presser (1899-1970) już w latach 20. i 30. poświęcił się badaniu egodokumentów. Po wojnie, jako profesor Uniwersytetu w Amsterdamie, zajmował się historią holenderskich Żydów w czasie nazistowskiej okupacji. Pracując nad tym zagadnieniem, zwrócił szczególną uwagę na osobiste doświadczenia ofiar i sprawców Holokaustu zawarte w dziennikach, pamiętnikach i wywiadach, zob. R. Dekker, Introduction, [w:] Egodocuments and history: autobiographical writing in its social context since the middle ages, red. tenże, Rotterdam 2002, s. 7-17.

2 Niektórzy uczeni posługują się określeniami: self-narratives, testimonies to the self, Selbstzeugnisse („samoświadectwa”), zob. M. Fulbrook, U. Rublack, In Relation: The "Social Self” and Ego-Documents, „German History” 2010, t. 28, nr 3, s. 263. 
Nauk Historycznych oraz Instytut Historii i Archiwistyki Uniwersytetu Mikołaja Kopernika. Spotkanie odbyło się 15 maja 2014 r. w Sali Rady Wydziału Nauk Historycznych w Collegium Humanisticum Uniwersytetu Mikołaja Kopernika. Program spotkania obejmował dziewięć wystąpień.

Otwarcia obrad i przywitania prelegentów oraz gości dokonał prodziekan Wydziału Nauk Historycznych UMK prof. dr hab. Wiesław Sieradzan oraz Dyrektor Instytutu Historii i Archiwistyki prof. dr hab. Jacek Wijaczka. Obaj wyrazili zainteresowanie koncepcją egodokumentu, a także podkreślili wartość świeżego spojrzenia na istniejące i znane badaczom źródła rękopiśmienne, które może zaowocować nowymi ustaleniami i odkryciami.

Jako pierwsi, z Doświadczeniami i perspektywami badań nad piśmiennictwem przestrzeni prywatnej wystąpili profesor Stanisław Roszak oraz profesor Waldemar Chorążyczewski z Uniwersytetu Mikołaja Kopernika w Toruniu. Uczeni w swoim wystąpieniu wprowadzili uczestników w zaproponowany przez Jacoba Pressera w latach 50. pomysł analizy źródeł autobiograficznych. W dalszej części wystąpienia skupili się na teorii i klasyfikacji piśmiennictwa prywatnego. Profesor Roszak wskazał na różnice w przyjętych przez badaczy metodologiach oraz ewolucję koncepcji Pressera. Dla klarowności zaproponował schemat obejmujący wszystkie rodzaje źródeł autobiograficznych analizowanych przez historyków.

Następnie głos zabrał Arvydas Pacevičius z Wydziału Komunikacji Uniwersytetu Wileńskiego. W swoim wystąpieniu profesor Pacevičius przedstawił rozpoczęty w 2008 r. Litewski program badania egodokumentów - LEGODOK. Celem finansowanego przez Litewską Radę Badań Naukowych projektu była inwentaryzacja dziedzictwa litewskiego z zakresu piśmiennictwa prywatnego, a w konsekwencji prezentacja litewskich egodokumentów poza Litwą, tak aby mogły być włączone w obieg europejski i rozpatrywane w tym kontekście. Prelegent podkreślił, że oprócz wydawnictw źródłowych w formie książkowej oraz wirtualnej biorąca udział w projekcie międzynarodowa grupa badaczy stworzyła bibliografię litewskich egodokumentów, a także spis teoretycznych prac poświęconych teorii piśmiennictwa przestrzeni prywatnej. Na sam koniec prof. Pacevičius omówił funkcje rękopiśmiennego egodokumentu.

Dzięki szeroko zakrojonym kwerendom i pracom inwentaryzacyjnym programu LEGODOK możliwe było dotarcie do wcześniej niedostępnych źródeł rękopiśmiennych rozsianych po bibliotekach i archiwach Litwy. Tak dostępne materiały stały się przedmiotem mikroanaliz wielu badaczy. Do nich należy magister Joanna Orzeł z Uniwersytetu Mikołaja Kopernika w Toru- 
niu, która omówiła wydany w ramach LEGODOK Dziennik podróży Józefa Jerzego Hylzena z lat 1752-1754. W ten sposób badaczka przeniosła uczestników konferencji do konkretnego egodokumentu - dziennika podróży. Autorka nakreśliła kolejne etapy Grand Tour młodego szlachcica, na który składały się: nauka w wiedeńskim Collegium Theresianum, wizyty na dworze w Monachium i Berlinie oraz ponad roczny pobyt w Paryżu. Analizowany diariusz posłużył referentce jako przykład ukazania zmian zachodzących w piśmiennictwie pamiętnikarskim XVIII w., zmierzających w stronę zapisek o charakterze bardziej osobistym, uczuciowym.

Nawiązaniem do poprzedniego referatu było wystąpienie magistra Łukasza Wróbla. Referat Dziennik J. J. Hylzena z lat 1754-1759 w kontekście historycznym, politycznym i socjologicznym także został poświęcony pojedynczemu egodokumentowi - dziennikowi. Prelegent rozpoczął od zagadnień związanych ze strukturą i formą diariusza, jak również podjął zagadnienie relacji między dokumentami pióra jednego autora. Następnie przeszedł do treści pojawiających się w obrębie źródła. Podkreślił, że na nie składają się refleksje dotyczące ludzi, wydarzeń oraz miejsc odwiedzanych przez piszącego. Referent zauważył, że w omawianym rękopisie, podobnie jak w innych egodokumentach epoki, dominuje opis świata zewnętrznego. Czasem, obok zrutynizowanej relacji w stylu protokolarnym, pojawiają się fragmenty, w których opis się rozszerza. W nich diarysta zapomina o staropolskiej powściągliwości, co umożliwia nam stworzenie mentalności i świata wartości autora.

Kolejny referat - Egodokumenty jako źródto do dziejów politycznych Litwy międzywojennej na przyktadzie dziennika Jurgisa Šaulysa - zaprezentowany został przez litewskiego historyka, działacza społecznego, polityka oraz ambasadora Litwy w Szwajcarii - Vytautasa Plečkaitisa. Na początku wystąpienia prelegent przedstawił sylwetkę samego Šaulysa - litewskiego polityka i dyplomaty, sygnatariusza aktu niepodległości Litwy z 1918 r. W dalszej części skupił się na pismach Šaulysa z okresu międzywojennego, kiedy ten pełnił funkcje dyplomatyczne. Plečkaitis, sam posiadający doświadczanie polityczne, zwrócił uwagę na specyfikę i trudność odczytu egodokumentów Šaulysa.

Po pięciu referatach nastąpiła dyskusja. Następnie prof. Roszak zamknął tę część obrad i zaprosił uczestników na przerwę obiadową. Po niej obrady wznowiono pod przewodnictwem prof. Arvydasa Pacevičiusa.

Pierwszym wystąpieniem po przerwie był referat doktor Agnieszki Rosy z Uniwersytetu Mikołaja Kopernika Egodokumentalność dziennika podróży Michata Butlera z lat 1779-1780. Wypowiedź składała się z trzech części. Po 
kilku wstępnych rozważaniach teoretycznych prelegentka omówiła dziennik podróży Michała Butlera do Włoch i Niemiec, zawarty w nim opis kolejnych jej etapów, kwestie związane z problemem ustalenia autorstwa oraz zagadnienia genologiczne. W ostatniej części swojej wypowiedzi dr Rosa podkreśliła, że egodokumentalna analiza diariusza pokazuje, jak wiele można dowiedzieć się o początkowo bezimiennym autorze tekstu. Pozwala ona określić jego wyznanie, przynależność państwową oraz pochodzenie etniczne, a przede wszystkim zainteresowania. Dzięki takiej analizie można też dojść do bardziej ogólnych wniosków, gdyż wyłaniające się z dziennika uwagi charakteryzują współtowarzyszy diarysty, w tym fundatora podróży Michała Butlera, oraz obrazują w pewnym zakresie umysłowość epoki.

Jako drugi w popołudniowym panelu wystąpił Arūnas Vyšniauskas z Uniwersytetu Wileńskiego z tematem Sprawozdania z pobytu wilnie. Przyktady wspótczesnych studenckich egodokumentów. Doktor Vyšniauskas przeniósł uczestników do współczesnych egodokumentów i zaprezentował efekty pracy ze stworzonymi przez studentów z różnych państw europejskich studiujących na Uniwersytecie Wileńskim w ramach programu Erasmus relacjami. Prelegent podkreślił, że są to źródła cenne, gdyż powstały w perspektywy „obcego”. Ponadto w swoim wystąpieniu Vyšniauskas omówił funkcje pozostawionych świadectw i bazę, w której są zbierane i analizowane.

Kolejny referat pt. Świat i ludzie w pamiętniku Ryszarda Mienickiego przedstawił dr hab. Robert Degen z Uniwersytetu Mikołaja Kopernika w Toruniu. Na początku swojego wystąpienia prelegent przybliżył uczestnikom sylwetkę profesora wileńskiego i toruńskiego uniwersytetu, dyrektora Archiwum Państwowego w Wilnie. Następnie autor przeszedł do analizy egodokumentów pozostałych po Ryszardzie Mienickim. Szczególnie w pierwszoosobowym pamiętniku, w opiniach o innych uczonych, refleksjach na temat bieżących wydarzeń znajdujemy osobowość Mienickiego. Prelegent podkreślił, że po II wojnie światowej, po przenosinach uczonego z Wilna do Krakowa i Torunia pamiętniki dają obraz zmian światopoglądowych uczonego, co pokazuje, jak ważne jest odczytywanie egodokumentów przez pryzmat biograficzny.

Jako ostatni wystąpił magister Piotr Bewicz z interesującym i prowokującym tematem: Historyk wobec egodokumentu. Intymnośc i granica. Prelegent, snując rozważania wokół dwóch tekstów: Maryanne Dever Greta Garbo's foot, or, sex, socks and letters oraz Dever, Sally Newman i Ann Vickery The Intimate archive: journey through the private papers, starał się odpowiedzieć na kilka pytań: przede wszystkim dotyczących granicy, którą historyk może osiągnąć, 
pracując z egodokumentem oraz tego, jak daleko te granice może przesuwać. Autor zastanawiał się, na ile obecne w dyskursie „pragnienie obecności” może stać się reprezentacją tego, co już nieobecne, bez jednoczesnego tracenia rysu historycznej narracji. Oprócz tego magister Bewicz podkreślił silną rolę „przedstawienia” i „reprezentacji” w konstruowaniu narracji historycznej.

Po wysłuchaniu wszystkich referatów podsumowania konferencji dokonał prof. Roszak oraz prof. Chorążyczewski.

Konferencja „Egodokumenty. Tradycje historiograficzne - perspektywy badawcze" zaprezentowała interesującą, mniej znaną w Polsce koncepcję analizowania źródeł rękopiśmiennych. Spotkanie pozwoliło spojrzeć na polskie oraz litewskie piśmiennictwo prywatne w kontekście europejskim. Sympozjum pokazało, w jaki sposób można stawiać nowe pytania znanym już źródłom. Uwidoczniło również fakt, że współcześni badacze odeszli od oryginalnej koncepcji zaproponowanej ponad pół wieku temu przez Pressera odeszli oraz różnice w metodologiach i analizowanych obszarach w różnych państwach.

Na podstawie wygłoszonych referatów należy podkreślić interdyscyplinarność konferencji. Najliczniej reprezentowani na spotkaniu byli historycy, którzy pochylili się nad rozważaniami teoretycznymi i relacją prywatne-publiczne w egodokumentach obszaru polsko-litewskiego. Niezwykle cenne jest, że obok refleksji genologicznej kilku badaczy zaprezentowało swoje doświadczenia w pracy nad konkretnymi egodokumentami. Dzięki temu konferencja stała się miejscem wymiany doświadczeń, problemów, a także osiągnieć. Sporą grupę reprezentowali archiwiści, którzy oprócz uwag natury teoretycznej podjęli zagadnienie granicy, którą badacz powinien lub nie powinien przekraczać w pracy ze źródłem o charakterze prywatnym.

„Egodokumenty. Tradycje historiograficzne - perspektywy badawcze” umożliwiły przegląd metodologii oraz prac nad piśmiennictwem sfery prywatnej prowadzonych przez różne ośrodki w Polsce i na Litwie. Jednych z zadań sympozjum było podsumowanie osiągnięć programu LEGODOK, w ramach którego polsko-litewska grupy badaczy zajmowała się egodokumentami terenu litewskiego. Konferencja z pewnością osiągnęła te cele i należy oczekiwać kolejnej międzynarodowej współpracy, a także tomu pokonferencyjnego, który przybliżyłby nowe koncepcje oraz zawarte w wystąpieniach prelegentów efekty pracy z egodokumentami.

Eukasz Wróbel

(Uniwersytet Mikołaja Kopernika w Toruniu) 